\title{
Investigation of Mall Atmosphere in Experiential Shopping During Holiday Season: A case of Malaysian Shopping Malls
}

\author{
Derek Ong Lai Teik*, Gan Yi Hao**, Iva Juniaty***, Joseanne Wong Lirn \\ Jhet $^{* * * *}$, Ling Ai Rick ${ }^{* * * * *}$ and Subashini a/p Gullantheivello*****
}

\begin{abstract}
This study examines the influence of environmental factors in a shopping mall on consumer behaviour especially during holiday season. Within a shopping mall there needs to be a balance of external environment elements that serves to elicit human stimuli to help induce different sensations and psychological effects on a person, ultimately leading to positive consumer behaviours and increased purchase intentions. However the wrong balance of these elements can hinder the positive reactions of consumers especially during the holiday season shopping where potentially sales are at the highest. This study employed a convenience sampling data collection method from 300 respondents in a selected shopping mall during the month of December 2013 to capture the consumer's reaction to the mall's atmosphere which were enhanced with festive decorations to help induce potential buying behaviour. Results were collated based on the analysis of four significant environmental variables which are interior settings, music, employee engagement and consumer density. The findings indicated that the effects of interior settings, music and employee engagement were found to be evident. Conversely, consumer density was found to elicit no effect on consumer behaviour. It was also noted that gender moderates the relationship between music and consumer behaviour. The implications of the results obtained are discussed along with the managerial implications, limitations and future research.
\end{abstract}

JEL Codes: M31

\section{Introduction}

Shopping has become an activity of leisure and most of the stress of it has been reduced with the introduction of online shopping in recent years. Nevertheless, shopping mall operators are constantly improving their current operations to enhance customer experience. Besides, shopping malls are enclosed environment with controlled climate and on-site parking. The amount of time an individual spent in a mall as well as the frequency of an individual to engage in shopping are fundamental reasons for shopping mall operators to continue to elicit stimulation to enhance their positive consumer behaviour and increase their purchase intention probability. Besides the potential in high sales, holiday seasons are a great opportunity for shopping mall operators to enhance their stimulations through various decorations and atmosphere manipulation of the interior design and ambience.

\footnotetext{
* Dr. Derek Ong Lai Teik, Senior Lecturer, Department of Marketing, Sunway University Business School, MALAYSIA, email: dereko@sunway.edu.my

${ }^{* *}$ Gan Yi Hao, Sunway University Business School, MALAYSIA, email: fredgyh@gmail.com

${ }^{* * *}$ Iva Juniaty, Sunway University Business School, MALAYSIA, email: ivajuniaty@gmail.com

****Joseanne Wong Lirn Jhet, Sunway University Business School, MALAYSIA, email: joseanne818@gmail.com

*****Ling Ai Rick, Sunway University Business School, MALAYSIA, email: rickling@gmail.com

****** Subashini a/p Gullantheivello, Sunway University Business School, MALAYSIA, email:

bluelavender16@hotmail.com
} 


\section{Ong, Gan, Juniaty, Wong, Ling \& Gullantheivello}

This study was fundamentally executed to explore beyond the various investigations of past researchers (Michon, Chebat and Turley, 2005; Bloch, Ridgway and Dawson, 1994; Chebat and Morrin, 2007) regarding the effects of shopping malls' ambience towards consumer behaviour. However these papers did not look into the effects of holiday season ambience decoration and atmosphere which is the central theme of this study. The variables involved in this study include interior settings (colour, decorations and lighting), music, consumer density and employee engagement. Thus, it is of primary importance to discover if these elements play a role in attracting consumers to visit certain malls during the festive seasons as well as the aspects that influence an individual to stay longer in a particular mall. Hereinafter, the current research will be able to provide shopping mall management with the opportunity to enhance significant aspects of a mall ambience during upcoming festive seasons through the acquisition of reliable data. Therefore this research seeks to investigate the effects of various aspects of a shopping mall towards consumer behaviour during the holiday season.

The paper continues with an examination of literature on the various independent and dependant variables used for this study including the integration of the Theory of Reasoned Action and the Approach-Avoidance Behaviour model into the study framework. Each variable relationship explanation is followed by the development of testable hypothesis. The methodology section shows the theoretical framework used for this study along with the sampling design and data collection methods. This is followed by the adaptation of the various sources to develop the instrument used for this study, whereby pilot test on reliability was performed and reported. The findings report the descriptive statistics and the main hypothesis results from analysis. Lastly the paper finishes with a brief explanation of the implications of the findings on the theory and industry as well as reviews the limitations of the study for future research considerations.

\section{Literature Review}

\subsection{Shopping Atmosphere and Effects on Consumer Behaviour}

Shopping malls supply shopping basic needs through the group of stores such as retail shops and restaurants within a single structural design of a shopping mall as presented by Abrudan (2011). Spangenberg, Grohmann and Sprott (2005) suggested that shopping malls should elicit the consumers' sentiment during any festive seasons by creating an atmosphere relevant to the respective festivals. Similarly, Kotler (2001) believed that the shopping mall ambience produce greater effects on consumer behaviour compared to the products and services offered in the mall. In their study, Bloch et al (1994) has indicated that consumers' interaction with functional aspects of the mall is inevitable because the consumers want to be there to be entertained. This means that the more variety of stimulation the mall provides, the more interaction between consumers and the environment can occur providing more opportunity for external stimulation of consumer behavior. Chebat and Morrin (2007) suggests that the décor within a mall effects the perceptual enhancement of a consumer and it is largely mediated by cognitive rather than affective effect mechanisms, which means that during the holidays season this would be in the advantage of the mall to install decorations that help consumers relieve their attachment to tradition and values of the season. Michon et. al. (2005) further suggests that ambience creates a positive effect on retail density especially if the density if controlled suggesting that there may be a need to balance shopping crowds and intended ambience during the holiday season. Although these papers suggest that the positive relationships of internal mall elements and consumer behavior, interestingly enough not much has been 


\section{Ong, Gan, Juniaty, Wong, Ling \& Gullantheivello}

looked into how holiday season enhanced decoration and ambience could be used to enhance consumer purchase intention.

\subsection{Theory of Reasoned Action (TRA) Model}

Figure 1: Theory of Reasoned Action Model

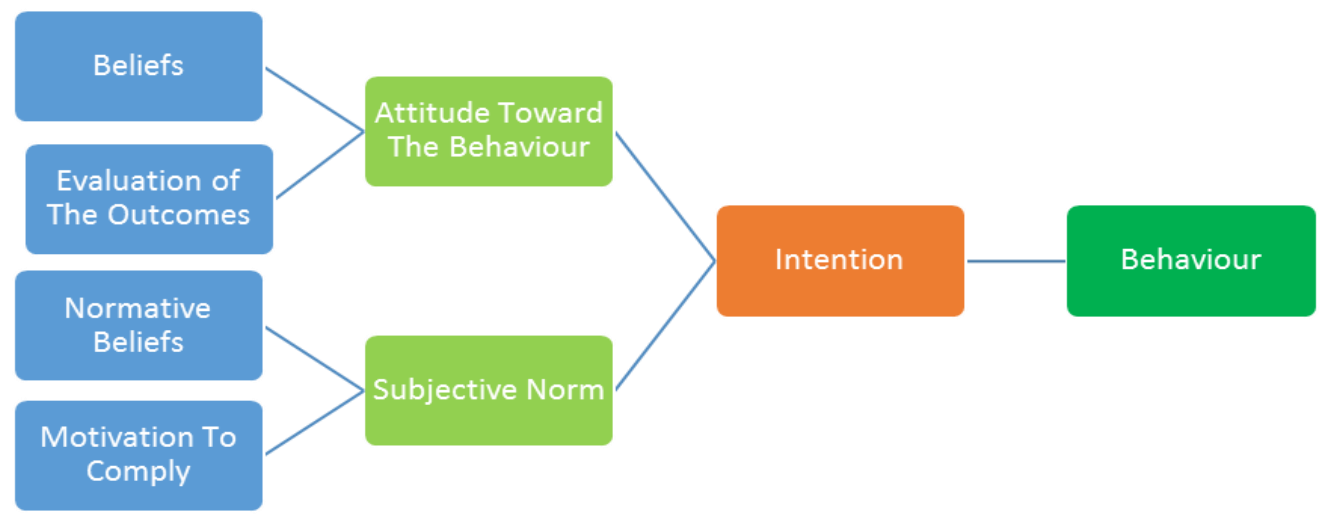

The theoretical framework was established based on the theory-of-reasoned action (TRA) developed by Martin Fishbein and Icek Ajzen that explicates the attitude-behaviour relationship as illustrated in Figure 1. The model denotes a comprehensive combination of the attitude elements that is constructed to provide better elucidation and prediction of individuals' behaviour (Schiffman and Kanuk, 2007). Hale, Householder, and Greene (2002) also explained that it is necessary to first discern the individuals' behaviour intention to predict their volitional behaviour in the TRA model. The authors further mentioned that a person's behavioural intention can be determined by the results of two components, namely the individual's attitude towards performing the behaviour as well as the subjective norms. According to Schiffman and Kanuk (2007), attitude refers to an individual's noticeable favourable or unfavourable orientation towards performing the behaviour, which means that an individual's attitude towards his or her behaviour is determined by a combination of an assessment of the individual's belief concerning the outcome arising from the behaviour and evaluation of the outcome of that behaviour to be judged in either a positive or negative way (Hale, et al., 2002). Subjective norm is defined as the perceived influence that an individual received based on other individual's perceptions, social pressure or beliefs (Schiffman and Kanuk, 2007). Apart from that, a subjective norm comprises of the normative beliefs where the influence of other referents is significant on an individual's perception and expectation to perform his or her behaviour as well as the individuals' motivation to comply with the desire of these referents (Chiou, 1998)

\subsection{Approach-Avoidance behaviour of the Shopper}

The atmospheric effects measure the dependent variable of the approach-avoidance behaviour in this research proposal. Mehrabian and Russell (1974) suggested that this model is based on all responses towards the environment encompassing four aspects as follows:

1. The desire to physically stay (approach) or leave (avoid) the environment.

2. The desire and willingness to explore the environment (approach) against the propensity to avoid interacting or moving through the environment as well as the propensity to remain inanimate in the surrounding environment (avoidance). 


\section{Ong, Gan, Juniaty, Wong, Ling \& Gullantheivello}

3. The desire and willingness to communicate with others in the environment (approach) against the propensity to avoid communications with others or to ignore interaction attempts from others (avoidance).

4. The degree of enhancement (approach) or hindrance (avoidance) regarding the performance and satisfaction with the required task performances.

The approach-avoidance behaviour also comprises three emotional states in response to the environment, namely pleasure (P), arousal (A) and dominance (D) (Turley and Milliman, 2000; Turley, et al., 2002; Donovan and Rossiter, 1982; Bohl, 2012). Urban consumers are constantly evaluating the ambient quality and the extent of stimuli experienced during shopping which relates to the scenario of the research (Rajagopal, 2011). The author further suggested that higher levels of approach are apparent in a congruent environment while the avoidance behaviour is exhibited in a less conducive environment.

The ambience of a shopping mall is governed by factors such as consumer density (Turley, et al., 2000). Ryu and Jang (2008) stated that background music is a contributing factor to an individual's impression on the environment. The authors also attributed the increase in awareness towards the interior settings in a mall. Furthermore, they stated that employees' engagement with the consumers will ultimately influence the level of the consumers' pleasantness and arousability.

\subsection{Interior Settings}

Interior settings play a predominant role in affecting consumers to visit the mall. According to Berman and Evans (1995), interior settings fall under the category of general interior variables which include flooring, lighting, scents and sounds, temperature, cleanliness, wall textures and colour usage. However, the study is emphasising on lightings, colour schemes and décors in the shopping malls. Grossman and Wisenblit (1999) discovered that consumers often follow the norms of their colour choices based on the associations developed through experience. Hence, it is mandatory for the marketers to understand the factors that influence consumers' colour decisions. Sirgy, Grewal and Mangleburg (2000) argued that the shopping mall ambience such as appropriate colours and lightings will attract customers to the mall. In addition, Wakefield and Baker's (1998) field study illustrated that environmental factors such as designs and décors portray a significant relationship to the excitement and desire of the customers to linger in the shopping mall. Researchers assumed that interior settings in the mall will develop positive relationship towards consumers' behaviour. This postulates the hypothesis:

$\boldsymbol{H}_{1}$ : There is a relationship between interior settings and customer behaviour.

\subsection{Music}

Music is another important ambient factor in the shopping mall that affects the consumers' approach-avoidance behaviour. This is supported by Wakefield, et al. (1998) stating that music played in the shopping mall can induce a positive influence on the consumer's desire to stay longer in the mall which is attributed to their positive perception of the mall environment. Besides, the introduction of Christmas music was found to be an effective practice that captures consumers' attention to visit their stores as music is believed to evoke the feeling of Christmas spirit and season (Spangenberg, et al., 2005). Likewise, Eroglu, Machleit and Chebat (2005) discovered that the effects of music tempo had an effect on the approach-avoidance tendency towards the store as well as the extent to which 


\section{Ong, Gan, Juniaty, Wong, Ling \& Gullantheivello}

customers explore the store environment. Moreover, Yalch and Spangenberg (1988) stated that younger shoppers who were exposed to the background music tend to spend more time to shop while older shoppers showed similar tendency in the presence of foreground music. Milliman (1986) discovered that the behaviour of patrons were affected by soothing background music whereby patrons are likely to spend more time in the restaurant in the presence of slow-tempo music whilst Herrington's (1996) research study provided that the customers' music preference regardless of the music tempo and/or volume also played an important role to influence the amount of time customers spent in the supermarket. Music ambience was found to affect consumers' behaviour from previous researches. However, it is essential to perform further research and analysis to verify that music significantly influences consumer behaviour. This postulates the hypothesis:

\section{$\boldsymbol{H}_{2}$ : There is a relationship between music and consumers behaviour.}

An individual's gender serves as a moderating factor that alters the impact of music ambience on the consumer's behaviour. Similar environmental dimension in general would affect males and females to respond in a different way (Mehrabian, et al., 1974). Besides, Yalch and Spangenberg (1993) argued the store was seen to be more mature for the female shoppers when background music was played whereas male shoppers discerned the store to be more mature when foreground music was played. In addition, Peretti and Swenson (1974) explained that there were significant distinction between female and male in giving responses to the music. The effects of music are more consistent among female responses as the diminution in anxiety levels for females are greater than that of males. All of the aforementioned research studies suggested that gender has a considerable impact as a moderating effect between music and the consumer behaviour. Thus, this postulates the third hypothesis:

\section{$\boldsymbol{H}_{3}$ : Gender has moderating effect between music and consumers' behaviour.}

\subsection{Consumer Density}

According to Machleit, Kellaris and Eroglu (1994), consumer density was shown to be a critical element in affecting consumers' behaviour. Likewise, Hui and Bateson (1991) also discovered that high levels of consumer density would lead to negative shopping experience among the shoppers due to limited space. Besides, consumer density will have greater negative effect on shopping satisfaction for consumers with lower tolerance level for crowds (Machleit, Eroglu and Mantel, 2000). However, consumer density produces both positive and negative behavioural effect towards consumers depending on the settings (Hui, et al., 1991). For instance, high level of consumer density affects shopping satisfaction positively in a discount-type store whereas consumer density is negatively correlated with satisfaction in an upscale store (Machleit, et al., 2000). Therefore, it may be speculated that consumer density imposes a crucial impact on consumer behaviour which then leads to the fourth hypothesis.

$\boldsymbol{H}_{4}$ : There is a relationship between consumer density and consumer behaviour.

\subsection{Employee Engagement}

Employee engagement is described as an individual's passion and the commitment in his or her job (Ariani, 2012). The employee's behaviour and the way their duties are conducted will influence the customers' behaviour in the mall (Turley, et al., 2002). Besides, retail 


\section{Ong, Gan, Juniaty, Wong, Ling \& Gullantheivello}

employees play a role in affecting shoppers' satisfaction level (Turley, et al., 2000). Correspondingly, it was stated that shopping mall management must provide optimal security and cleanliness services to achieve shoppers' satisfactory level (Kimani, Kagira, Kendi, Wawire and Fourier, 2012; Khairul, 2013). According Kimani, et al. (2012), the attitude of an employee which includes friendliness and helpfulness will determine the consumer's store selection. Thus, it evokes a positive vibrant between the consumers and employees. Furthermore, Merrilees and Birch (2003) also suggested that the services provided in the shopping centre are confined with the employee's knowledge, sociability and courteousness. Moreover, the appearance and the professionalism of the employee will affect the customer's provenance and satisfaction (Bitner, 1990). The impact of employee services on consumers' shopping behaviour is evident based on the findings from previous studies as discussed which leads to the hypothesis:

$\boldsymbol{H}_{5}:$ There is a relationship between employee engagement and consumer behaviour.

\section{The Methodology and Model}

\subsection{Theoretical Framework}

To test the hypotheses, a theoretical framework as shown in Figure 2 was developed that shows the relationship between the independent and dependant variables in this research study in accordance to the TRA model explained earlier. The independent variables which are music, interior setting and consumers' density represent the attitude of an individual towards performing the behaviour whilst employment engagement represents the subjective norm. These independent variables are able to affect the individual's approach-avoidance behaviour.

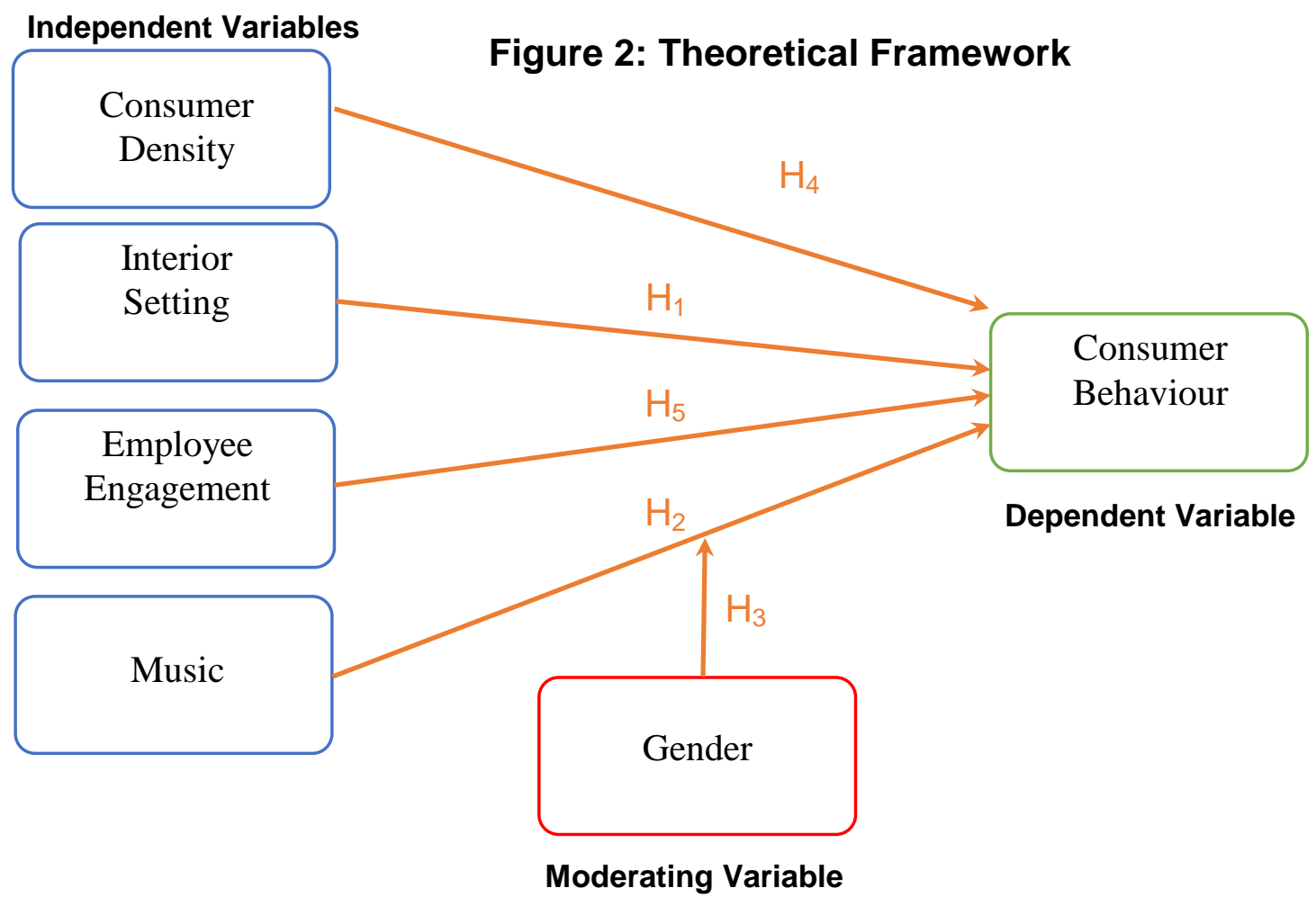




\section{Ong, Gan, Juniaty, Wong, Ling \& Gullantheivello}

\subsection{Sampling Design}

Convenience sampling was used in this research to select the appropriate target population which consists of the male and female respondents. The sample population that was determined for this study were shoppers in Malaysia. The quantitative method involved the equal distribution of 300 questionnaires to 150 males and 150 females shoppers respectively in Sunway Pyramid Shopping Centre to correspond with the gender moderating effects aforementioned. The means of the variables by genders in this study is shown in table 4 and is explained in further detail. These shoppers would represent other shoppers in other shopping malls in Malaysia. The data was collected from the period of December $1^{\text {st }} 2013$ till January $1^{\text {st }} 2014$ in to correspond with the consumers' perception about the mall ambience in line with the holiday season of Christmas. Permission to distribute the questionnaires was granted by Sunway Pyramid Centre Management Office prior to commencing the research within the specific areas provided in the shopping mall.

\subsection{Data Collection Method}

Primary and secondary data were collected for the purpose of this research study. The secondary data was first collected, used and compiled in the literature review to clarify the research problem and discover the independent variables that would affect consumer behaviour in the mall during Christmas. Next, primary data was collected from both quantitative and qualitative data. Firstly, quantitative data is obtained through questionnaire and thus the pilot test is essential to be conducted before the distribution of the actual questionnaire. The pilot test was conducted twice in Sunway University and Sunway Pyramid Mall by selecting a total sample of 50 respondents comprising of 25 males and 25 females. Such distribution is crucial as gender is the moderating factor between music ambience and consumer behaviour. Ultimately, the actual questionnaires were distributed to 300 respondents with the aim that the generalised results can be concluded to validate our findings from the secondary research. Hence, these data were analysed by a set of statistical tools to test the hypotheses.

\subsection{Instrument Design}

In order to ensure accurate measurements for the variable indicated for this study, several measurements were adapted into the questionnaire that were distributed for this study and is indicated in Table 1 below. Previous studies (Michon et. al, 2005; Bloch, Ridgway and Dawson, 1994; Chebat and Morrin, 2007) have included most of the variables on ambience and atmosphere, however to further understand the positive effects on consumer behavior, the variable employee engagement is further added in this study. As mentioned, during holiday season, most shoppers would like to ensure that their shopping is done precisely right and without hassle and will seek assistance on this. Friendly, helpful and knowledgeable staff can be a positive contributing factor. 


\section{Ong, Gan, Juniaty, Wong, Ling \& Gullantheivello}

Table 1: List of Instrument Adapted

\begin{tabular}{|l|l|l|l|}
\hline Sections & Variables & $\begin{array}{l}\text { Gescription } \\
\text { Information }\end{array}$ & \multicolumn{1}{l|}{ Sources } \\
\hline Part A & - & & Wakefield, et al. (1998) \\
\hline Part B & Interior Settings & Music & $\begin{array}{l}\text { Obermiller (1985); North, } \\
\text { Hargreaves and McKendrick (1999); } \\
\text { Ramos (1993); Wakefield, et al. } \\
\text { (1998); Spangenberg, et al. (2005); } \\
\text { Herrington, et al. (1996) }\end{array}$ \\
\hline Part D & Consumer Density & & - \\
\hline Part E & Employee & & $\begin{array}{l}\text { Ahmad (2012); Parasuraman, Berry } \\
\text { and Zeithaml (1991); Wakefield, et } \\
\text { al. (1998) }\end{array}$ \\
\hline Part F & $\begin{array}{l}\text { Congagement } \\
\text { Behaviour }\end{array}$ & & $\begin{array}{l}\text { Mehrabian, et al. (1974); Babin, } \\
\text { Darden and Griffin (1994) }\end{array}$ \\
\hline Part G & - & Demographic & - \\
\hline
\end{tabular}

\subsection{Factor Analysis and Reliability of Measures}

Table 2: Original Variables from Theoretical Framework

\begin{tabular}{|l|l|}
\hline Variables & Variables Description \\
\hline IS1 to IS5 & Interior Settings \\
\hline M1 to M9 & Music \\
\hline CD & Consumer Density \\
\hline EE1 to EE8 & Employee Engagement \\
\hline CB1 to CB7 & Consumer Behaviour \\
\hline
\end{tabular}

1. Consumer Behaviour is the dependant variable, thus was not subjected to factor analysis

The original variables from the instrument were listed in Table 2 and they were reduced to 4 through Varimax Rotation in factor analysis which is shown in Table 3. Bartlett's Test of Sphericity $(0.814)$ and KMO $(p<0.05)$ shows that the new variables are significant.

Table 3: New Variables after Factor Analysis and Reliability Tests

\begin{tabular}{|l|l|l|l|}
\hline Variables & $\begin{array}{l}\text { No. of } \\
\text { Items }\end{array}$ & \multicolumn{2}{c|}{ Item Variables } \\
\hline Interior Settings (IS) & 5 & IS1, IS2, IS3, IS4, IS5 & 0.856 \\
\hline Music (M) & 4 & M1, M2, M3, M5 & 0.793 \\
\hline $\begin{array}{l}\text { Employee Engagement } \\
\text { (EE) }\end{array}$ & 8 & $\begin{array}{l}\text { EE1, EE2, EE3, EE4, EE5, } \\
\text { EE6, EE7, EE8 }\end{array}$ & 0.836 \\
\hline Consumer Behaviour & 7 & $\begin{array}{l}\text { CB1, CB2, CB3, CB4, CB5, } \\
\text { CB6, CB7 }\end{array}$ & 0.906 \\
\hline
\end{tabular}

1. Consumer Behaviour is the dependant variable and thus, it is not subjected to factor analysis

Several variables from the original instrument are excluded due to low loadings $(<0.4)$. The reliability of the new constructs were tested and Cronbach's Alpha of all the new constructs are above 0.5 which is shown also shown in Table 3. 


\section{Ong, Gan, Juniaty, Wong, Ling \& Gullantheivello}

\section{Findings}

\subsection{Respondents Means}

Table 4: Respondents Means on Variables

\begin{tabular}{|c|c|c|}
\hline \multirow{2}{*}{ VARIABLE } & \multicolumn{2}{|c|}{ GENDER } \\
\hline & MALE $(n=150)$ & FEMALE $(n=150)$ \\
\hline Interior Settings & 5.07 & 5.14 \\
\hline Music & 4.37 & 4.69 \\
\hline Consumer Density & 14.90 & 12.21 \\
\hline Employee Engagement & 4.55 & 4.51 \\
\hline Consumer Behaviour & 4.73 & 5.01 \\
\hline
\end{tabular}

The genders of the respondents are distributed equally in all of the 300 available data. Table 4 indicates the means of interior settings, music, employee engagement, and consumer behaviour (rated as 1 - extremely disagree to 7 - extremely agree) as well as consumer density (amount of people surrounding) by gender. Both genders generally agree that all of the variables under study affects their shopping behaviour at the mall. However, the atmospheric effects of the mall affected are more towards the female respondents as their overall mean for most of the variables are higher compared to male respondents.

\subsection{Regression Results}

Table 5: Model Summary for Dependant Variable (Consumer Behaviour)

\begin{tabular}{|l|l|l|l|l|}
\hline $\mathrm{R}$ & $\mathrm{R}$ Square & $\begin{array}{l}\text { Adjusted R } \\
\text { Square }\end{array}$ & $\begin{array}{l}\text { Std. Error of } \\
\text { the Estimate }\end{array}$ & $\begin{array}{l}\text { Durbin- } \\
\text { Watson }\end{array}$ \\
\hline $.567^{\prime}$ & .322 & .312 & .90137 & 2.047 \\
\hline 2. & Predictors: (Constant), CD, EE, M, IS & &
\end{tabular}

As depicted in Table 5, the $R$ square value of 0.322 attains a $32.2 \%$ of variation in consumer behaviour denoted by variables consisting of consumer density, employment engagement, music and interior settings. A Durbin-Watson value of 2.047 is shows that the model is within the acceptable range of \pm 2 .

Table 6: ANOVA for Dependant Variable (Consumer Behaviour)

\begin{tabular}{|c|c|c|c|c|c|}
\hline Model & $\begin{array}{l}\text { Sum of } \\
\text { Squares }\end{array}$ & df & $\begin{array}{l}\text { Mean } \\
\text { Square }\end{array}$ & $\mathrm{F}$ & Sig. \\
\hline $\begin{array}{l}\text { Regressio } \\
\text { n }\end{array}$ & 113.642 & 4 & 28.410 & 34.968 & $.000^{1}$ \\
\hline Residual & 239.678 & 295 & 812 & & \\
\hline Total & 353.320 & 299 & & & \\
\hline
\end{tabular}

1. Predictors: (Constant), CD, EE, M, IS

Table 6 shows that the regression model is significant $(p<0.01)$. 


\section{Ong, Gan, Juniaty, Wong, Ling \& Gullantheivello}

Table 7: Hypothesis Test Results

\begin{tabular}{|l|l|l|l|}
\hline Hypotheses & t-stats & Sig. & Decision \\
\hline $\mathrm{H} 1: \mathrm{IS} \rightarrow \mathrm{CB}$ & 4.857 & $\mathrm{p}<0.01$ & Supported \\
\hline $\mathrm{H} 2: \mathrm{M} \rightarrow \mathrm{CB}$ & 3.449 & $\mathrm{p}<0.01$ & Supported \\
\hline $\mathrm{H} 4: \mathrm{CD} \rightarrow \mathrm{CB}$ & 0.422 & $\mathrm{p}>0.05$ & Not Supported \\
\hline $\mathrm{H} 5: \mathrm{EE} \rightarrow \mathrm{CB}$ & 4.918 & $\mathrm{p}<0.01$ & Supported \\
\hline
\end{tabular}

Table 7 shows the hypothesis results between Consumer Behaviour and the independent variables. It shows that all independent variables have a positive relationship with Consumer Bahaviour except Consumer Density. The relationship between the independent variables and dependent variable is shown in the regression line below:

Consumer Behaviour $=1.073+0.289$ Interior Settings +0.155 Music +0.350 Employment Engagement +0.002 Consumer Density

\subsection{Moderation}

To perceive a greater understanding on consumer approach-avoidance behaviour, music was tested to check whether its relationship with consumer behaviour is moderated by gender. Table 8 shows significant difference in slopes for both genders, indicating the presence of gender as a moderating effect between music and consumer behaviour. Hence, $\mathrm{H}_{3}$ is supported.

The difference in moderation seem to show more when there are higher levels of musical atmosphere that complements the holiday season. Although generally both genders react positively to music, females tend to exhibit higher levels of consumer behaviour when the music reflects more of the holiday season.

Table 8: Slope Summary for Figure 3

\begin{tabular}{|l|l|l|l|}
\hline Gender & Simple Slope & t-value & \multicolumn{1}{l|}{ Sig. } \\
\hline Female & 0.381 & 5.3882 & $\mathrm{p}<0.01$ \\
\hline Male & 0.242 & 3.8264 & $\mathrm{p}<0.01$ \\
\hline
\end{tabular}

\subsection{Discussion of Results}

The hypothesis results explain most of the behaviours of consumers and the factors they consider to be important when visiting malls during the holiday season. The results can be explained further based on the Avoidance-Approach theory.

$\mathrm{H} 1$ and $\mathrm{H} 2$ indicates that there is a desire to physically stay (approach) within an environment the environment, when the environment allows for the right ambience of music and decoration. With the holiday season as a motivating driving force, carefully crafted decoration that is both aesthetically appealing and functionally stimulating can help consumers relieve their attachment to the tradition of the season and ultimately allow them to be comfortable with the environment with the hopes of boosting their desire to shop more. The right music can too be a good stimuli to sense memory and emotions that help soothe and encourage happiness within an individual and this too helps in attracting the right kind of environment to help enhance consumer behaviour attitudes. 


\section{Ong, Gan, Juniaty, Wong, Ling \& Gullantheivello}

H4 notes that consumer density does not really play a factor within the Malaysian context when it comes to shopping. Unlike in the West where generally people avoid crowds, Malaysians do not really worry themselves about the density of crowds in shopping malls. This exhibits Malaysians willingness to explore the environment (approach) against the propensity to avoid interacting or moving through the environment as well as the propensity to remain inanimate in the surrounding environment (avoidance). This means that Malaysian will still shop regardless of the presence of crowds. In fact, it may be perceived that Malaysians will go to a mall because it attracts crowds.

H5 exhibits the need of Malaysian shoppers for competent and courteous staff. In a country where its people are known for its hospitable nature, it is not uncommon to expect a certain amount of helpfulness from service staff. This shows that Malaysian shoppers show the desire and willingness to communicate with others in the environment (approach) against the propensity to avoid communications with others or to ignore interaction attempts from others (avoidance). During holiday season where there is bustling myriads of activities and promotions, shoppers generally would tend to seek information which helps them make consumer decisions that fit their desire. Having more helpful and knowledgeable staff during this season can be advantageous to many shopping mall management whilst boosting sales.

$\mathrm{H} 3$ reveals the moderating effects of gender on consumer behaviour when higher propensity of holiday related music is played. The results show that females in general have a degree of enhancement (approach) regarding the performance and satisfaction with the required task performances. This enhancement serves as a catalyst when the right kind of music in played while in the background of the shopping mall. It would be a good practice to balance the appropriate music for shoppers, and not just for one particular gender, but to ensure that the whole ambience of the shopping experience is maintained at its highest level for everyone to enjoy.

\section{Conclusion}

\subsection{Implications of Results}

This study has revealed that there are significant positive relationships between Interior settings, music, and employee engagement with consumer behaviour. The industry should recognise the role of interior settings towards the consumers' sentiment. Hence, prospective shopping malls may want to nurture an environment according to the predilection of consumers. Significantly, the findings derived from the influence of music on consumer behaviour are partially influenced by the moderation effect in terms of gender variation. This analysis enables active growing companies to identify the music preference of consumers, followed by the implementation of changes to accommodate the favours in hope for an enhanced psychological perception. The accessibility in acquiring information from various parts of the mall and employee engagement is precursor for a satisfactory experience among the consumers. Therefore, managers could introduce service desk at strategic corners of the mall to assist inquiries directed from the consumers.

This is contrasted by the non-significant relationship between consumer density and consumer behaviour. This is in contrast to the findings of Turley et. al.(2000) and Ryu and Jang (2008), where people would generally avoid crowds. This is an interesting finding as it indicates that Malaysian shoppers are indifferent to crowds during holiday season. This finding could help the Malaysian government to boost its efforts in creating more awareness 


\section{Ong, Gan, Juniaty, Wong, Ling \& Gullantheivello}

for the yearly Malaysian sale season which usually falls during the year end festive season and help to promote more internal marketing to the Malaysian public. Nevertheless, managers could introduce environmental designs to alter the shopping mall image further that will induce a constructive psychological effect among the consumers whilst shopping in a shopping mall. There should always be a balance between the need of attracting crowds and creating a conducive festive environment that can be shared and experienced comfortably by all mall visitors, albeit shopping or otherwise.

This study has confirmed that consumer behaviours can be further enhanced especially during the holiday season where external stimuli is easier to create and positively better received by the consumers. This study has shown that the Theory of Reason Action and the Approach- Avoidance model can explain the various consumer behaviour factors that helps consumers interact and explore shopping malls that is willing to invest in creating unforgettable shopping experiences for its customers especially during the holiday season.

\subsection{Limitations and Future Research}

Research within the shopping mall experience is still scarce as many more shopping malls continue to mushroom within the vicinity of Klang Valley. However, most of these shopping malls experience a shortage of parking spaces especially during the festive seasons. This research showed a low percentage for $\mathrm{R}$-Square and may have not included atmospheric variables such as parking availability (Turley, et al., 2000). Future research could include this variable as an important element to determine the pull factor for consumers to the shopping malls. The other limitation was that the entire research focused on data collection on a single shopping mall in Petaling Jaya, Malaysia. Hence, the findings may not be representative of all the shoppers in Malaysia in general. Therefore, researching other malls in Malaysia is required to examine the validity and reliability of the malls' atmospheric effects towards consumer behaviour.

\section{References}

Abrudan, I 2011, 'Definitions and classifications of shopping centres. International Conference "Marketing - from Information to Decision', vol. 1, no. 4, pp.9-20.

Ahmad, AEMK 2012, 'Attractiveness factors influencing shopper's satisfaction, loyalty and word of mouth: an empirical investigation of Saudi Arabia shopping malls', International Journal of Business Administration, vol. 3, no. 6, pp.101-112.

Ariani, DW 2012, 'The relationship between employee engagement, organizational citizenship behaviour and counterproductive work behaviour. International Journal of Business Administration, vol. 4, no. 2, pp. 46-56.

Babin, BJ, Darden, WR \& Griffin, MG 1994, 'Work and/or fun: measuring hedonic and utilitarian shopping value. Journal of Consumer Research, Inc., vol. 20, no. 1, pp.644656.

Bitner, MJ 1990, 'Evaluating service encounters: the effects of physical surroundings and employee responses', Journal of Marketing, pp.69-82 in Turley. L. W. and Milliman, $\mathrm{RE}, 2000$, 'Atmospheric effects on shopping behaviour: A review of the experimental evidence. Journal of Business Research, Elsevier Science Inc., pp.193-21.

Bloch, PH, Ridgway, NM \& Dawson, SA 1994, 'The shopping mall as consumer habitat', Journal of Retailing, vol. 70, no. 1, pp. 23-42.

Bohl, P 2012, 'The effects of store atmosphere on shopping behaviour: a literature review', Corvinus Marketing Studies, vol. 1, no. 1, pp.1-23. 


\section{Ong, Gan, Juniaty, Wong, Ling \& Gullantheivello}

Chebat, JC \& Morrin, M 2007, 'Colors and cultures: exploring the effects of mall décor on consumer perceptions', Journal of Business Research, vol. 60, no.3, pp. 189-196.

Donovan, RJ \& Rossiter, JR 1982, 'Store atmosphere: an environmental psychology approach' Psychology of Store Atmosphere, vol. 58, no. 1, pp.34-57.

Eroglu, SA, Machleit, KA \& Chebat, JC 2005, 'The interaction of retail density and music tempo: effects on shopper responses', Psychology \& Marketing, vol. 22, no. 7, pp.577589.

Hale, JL, Householder, BJ \& Greene, KL 2002, 'The Theory of Reasoned Action'. In: Dillard, JP \& Pfau, M 2002, The persuasion handbook: developments in theory and practice, Thousand Oaks: Sage Publications, Inc. pp.259-286.

Herrington, JD \& Capella, LM 1996, 'Effects of music in service environments: a field study, Journal of Services Marketing, vol. 10, no. 2, pp.26-41.

Hui, MK \& Bateson, JEG 1991, 'Perceived control and the effects of crowding and consumer choice on the service experience', Journal of Consumer Research, vol. 18, no. 1, pp.174-184.

Kimani. SW, Kagira, EK, Kendi, L, Wawire, CM \& Fourier, UJ 2012, 'Shoppers' perception of retail service quality: supermarket versus small convenience shops (Dukas) in Kenya', Journal of Management and Strategy, vol. 3, no. 1, pp.55-66.

Kotler, P 2001, 'Atmospheric as a marketing tool', Journal of Retailing, vol. 49, no. 4, pp.4864.

Machleit, KA, Kellaris, JJ \& Eroglu, SA 1994, 'Human versus spatial dimensions of crowding perceptions in retail environments: a note on their measurement and effect on shopper satisfaction', Marketing Letters, vol. 5, no. 2, pp.183-194.

Machleit, KA., Eroglu, SA \& Mantel, SP 2000, 'Perceived retail crowding and shopping satisfaction: what modifies this relationship?', Journal of Consumer Psychology, vol. 9, no.1, pp.29-42.

Martin, CA \& Turley, LW 2004, 'Malls and consumption motivation: an exploratory examination of older generation Y consumers, 'International Journal of Retail \& Distribution Management, vol. 32, no. 10, pp.464-475.

Mattila, AS \& Wirtz, J 2001, 'Congruency of scent and music as a driver of in-store evaluations and behaviour', Journal of Retailing, vol. 77, no. 1, pp.273-289.

Mehrabian, A \& Russell JA 1974, 'An Approach to Environmental Psychology', Cambridge, Mass: MIT Press.

Merrilees, JSB \& Birch, D 2003, 'Entertainment seeking shopping centre patrons: the missing segments', International Journal of Retail \&Distribution Management, vol. 31, no. 2, pp. 80-94.

Michon, R, Chebat, JC \& Turley, LW 2005, 'Mall atmospherics: the interaction effects of the mall environment on shopping behavior', Journal of Business Research, vol. 58, no. 5, pp. 576-583.

Milliman, RE 1986, 'The influence of background music on the behaviour of restaurant patrons', Journal of Consumer Research, vol. 13, no. 2, pp.286-289.

Parasuraman, A, Berry, LL \& Zeithaml, VA 1991, 'Refinement and reassessment of the SERVQUAL scale', Journal of Retailing, vol. 67, no. 4, pp.420-450.

Peretti, PO \& Swenson, K 1974, 'Effects of music on anxiety as determined by physiologocal skin responses', Journal of Research in Music Education, vol. 22, no. 4, pp.278-283.

Rajagopal 2011, 'Determinants of shopping behaviour of urban consumers', Journal of International Consumer Marketing, vol. 23, no. 1, pp.83-104.

Ryu, K \& Jang, SC 2008, 'Influence of restaurant's physical environments on emotion and behavioural intention', The Service Industries Journal, vol. 28, no. 8, pp.1151-1165. 


\section{Ong, Gan, Juniaty, Wong, Ling \& Gullantheivello}

Schiffman, LG \& Kanuk, LL 2007, Consumer Behavior, 9th ed. Saddle River: Pearson Education, Inc.

Spangenberg, ER, Grohmann, B \& Sprott, DE 2005, 'It's beginning to smell (and sound) a lot like Christmas: the interactive effects of ambient scent and music in a retail setting. Journal of Business Research, vol. 58, no. 11, pp.1583-1589.

Turley, LW \& Chebat, JC 2002, 'Linking retail strategy, atmospheric design and shopping behaviour', Journal of Marketing Management, vol. 18, no. 1, pp.125-144.

Turley, LW \& Milliman, RE 2000, 'Atmospheric effects on shopping behaviour: a review of the experimental evidence', Journal of Business Research, vol. 49, no. 1, pp.193-211.

Wakefield, KL \& Baker, J 1998, 'Excitement at the mall: determinants and effects on shopping response', Journal of Retailing, vol. 74, no. 4, pp.515-539.

Yalch, RF \& Spangenberg, E 1988, 'An Environmental Psychological Study of Foreground and Background Music as Retail Atmospheric Factors', in AMA Educators' Conference Proceedings, A.W. Walle, ed. Chicago: American Marketing Association, 106-110 in Mattila, AS \& Wirtz, J 2001, 'Congruency of scent and music as a driver of in-store evaluations and behaviour', Journal of Retailing, vol. 77, no. 2, pp.273-289.

Yalch, RF \& Spangenberg, E 1993, 'Using store music for retail zoning', Advances in Consumer Research, vol. 20, no. 1, pp.632-636. 